\title{
Perilaku Wanita Usia Subur dalam Pemilihan Alat Kontrasepsi Intra Uterine Device (Iud) di Fakultas Kesehatan Masyarakat UI Tahun 2018
}

\author{
Lidra Maribeth, $\mathrm{A}^{1}$, Aulia, $\mathrm{A}^{2}$, Adhani Pasundani, $\mathrm{N}^{3}$, Annisa Fauziyah, $\mathrm{N}^{4}$, Ma'rifah, Bidayatul \\ Tsalisatul Sua'idah, $\mathrm{S}^{5}$
}

${ }^{1}$ Bagian Ilmu Kesehatan Masyarakat Fakultas Kedokteran Universitas Baiturrahmah, Padang, Indonesia e-mail: annisalidramaribeth@gmail.com

${ }^{2}$ Bagian Ilmu Kesehatan Masyarakat Fakultas Kesehatan Masyarakat, Universitas Indonesia, Indonesia

${ }^{3}$ Bagian Ilmu Kesehatan Masyarakat Fakultas Kesehatan Masyarakat, Universitas Indonesia, Indonesia

${ }^{4}$ Bagian Ilmu Kesehatan Masyarakat Fakultas Kesehatan Masyarakat, Universitas Indonesia, Indonesia

${ }^{5}$ Bagian Ilmu Kesehatan Masyarakat Fakultas Kesehatan Masyarakat, Universitas Indonesia, Indonesia

\begin{abstract}
Abstrak
Latar belakang: Penggunaan metode kontrasepsi jangka panjang (MKJP) pada wanita usia subur di Indonesia masih tergolong rendah yaitu 4,7 persen. Salah satu jenis MKJP adalah intrauterine device (IUD). Mahasiswa Fakultas Kesehatan Masyarakat Universitas Indonesia (FKM UI) dinilai memiliki pengetahuan yang cukup terhadap MKJP. Tujuan: Menggali lebih dalam tentang perilaku wanita usia subur dalam pemilihan kontrasepsi IUD di FKM UI. Metode: Penelitian ini merupakan penelitian kualitatif dengan metode wawancara mendalam selanjutnya dianalisis dengan content analysis. Sampel penelitian adalah mahasiswi Pasca Sarjana FKM UI berusia 15-49 tahun yang telah menikah dan memutuskan menggunakan alat kontrasepsi. Sampel yang dipilih akan dibagi menjadi dua kelompok yaitu yang menggunakan IUD dan tidak menggunakan IUD. Hasil: dari penelitian ini diketahui bahwa faktor yang menghambat perilaku penggunaan kontrasepsi IUD adalah sikap dan faktor yang mendorong perilaku penggunaan IUD adalah dukungan suami. Intervensi yang mungkin dapat dilakukan adalah meningkatkan motivasi dan memperbaiki persepsi pengguna non IUD. Hal ini diharapkan dapat mengubah sikap pengguna non IUD dari tidak setuju menjadi setuju untuk menggunakan IUD. Selain itu peran dukungan suami perlu ditingkatkan dengan berbagai intervensi. Kesimpulan: Tidak terdapat perbedaan tingkat pengetahuan antara pengguna kontrasepsi IUD dan non IUD.
\end{abstract}

Katakunci : Perilaku wanita usia subur, intrauterine device (IUD), kontrasepsi jangka panjang, kualitatif

\begin{abstract}
Background: The use of long-term contraceptive methods in women of childbearing age in Indonesia is still relatively low (4.7\%). One type of long-term contraceptive methods is an intrauterine device (IUD). Students of Fakultas Kesehatan Masyarakat Universitas Indonesia (FKM UI) is considered to have sufficient knowledge of the long-term contraceptive methods. Objective: To explore the women behavior of childbearing age in the selection of IUD in FKM UI. Method: This research was a qualitative research with in-depth interview method then analyzed with content analysis method. The sample was FKM UI post graduate women students aged 15-49 years who have been married and decided to use contraception. The selected sample would be divided into two groups, those that used an IUD and didn't use an IUD. Results: this study noted that the factors that inhibit IUD contraceptive use behavior are attitudes and the factors that encourage IUD use behavior are husband support. Interventions that may be done are to increase motivation and improve the perception of non-IUD users. This is expected to change the attitude of non-IUD users from disagreeing to agreeing to use an IUD. In addition, the role of husband support needs to be enhanced with various interventions. Conclusion: There is no difference in the level of knowledge between IUD and non-IUD contraceptive users.
\end{abstract}

Keyword : Behavior of women of childbearing age, intrauterine devices (IUD), long-term contraception, qualitative.

Email : heme@unbrah.ac.id 


\section{Pendahuluan}

Setiap hari 830 wanita meninggal dikarenakan kehamilan dan persalinan dan 99 persen kematian ibu terjadi di negara berkembang. ${ }^{1}$ Indonesia merupakan salah satu negara berkembang yang masih memiliki angka kematian ibu (AKI) 359 kematian per 100.000 kelahiran hidup pada tahun 2012. ${ }^{2}$ AKI di Indonesia menurun menjadi 177 kematian per 100.000 kelahiran hidup pada tahun 2017. ${ }^{3}$ Angka ini masih jauh diatas rata-rata angka kematian ibu di Asia Tenggara, tahun 2015 rasio kematian ibu yaitu 160 per 100.000 kelahiran hidup. ${ }^{1}$ Dan masih jauh dari target Suistanable Development Goals (SDGs) yaitu 70 kematian per 100.000 kelahiran hidup. ${ }^{4}$

AKI dapat diturunkan jika dilakukan pencegahan dalam penyebab kematian ibu, salah satunya adalah dengan keluarga berencana (KB). Menurut Survey Demografi Kesehatan Indonesia (SDKI) tahun 2017 secara umum kelompok wanita usia subur (WUS) yang tinggal diperdesaan yang memiliki pendidikan rendah, lebih rendah pengetahuannya tentang kontrasepsi daripada wanita di perkotaan yang memiliki tingkat pendidikan lebih tinggi dan pengetahuan yang tinggi tentang kontrasepsi. Wanita usia subur sebanyak 63,6 persen menggunakan alat kontrasepsi dan 36,4 persen tidak menggunakan alat kontrasepsi. Sedangkan jenis kontrasepsi yang dipakai wanita kawin 15-49 tahun yang terbanyak yaitu suntik 29 persen, pil 12,2 persen, implant dan IUD masing-masing 4,7 persen, senggama terputus 4,7 persen, Metode operasi wanita (MOW) 3,7 persen, kondom 2,5 persen, pantang berkala 1,9 persen, Metode Operasi Pria (MOP) 0,02 persen dan Metode Amenore Laktasi (MAL) 0,1 persen. ${ }^{5,6}$

Strategi dan pelaksanaan program KB sendiri seperti tercantum dalam Rencana Pembangunan Jangka Menengah (RPJM) tahun 2015-2019 tentang terkendalinya jumlah dan laju pertumbuhan penduduk.
Salah satu kebijakan RPJM adalah meningkatkan penggunaan Metode kontrasepsi jangka penjang (MKJP). ${ }^{6}$

Hasil penelitian Rahayu (2017) menerangkan bahwa terdapat beberapa alasan yang mendasari rendahnya penggunaan KB MKJP oleh wanita usia subur di Kelurahan Gunung Terang yang berasal dari diri sendiri diantaranya takut efek samping dengan persentase terbesar, takut tindakan operatif atau pembedahan, kondisi kesehatan tidak mendukung, anggapan orang lain terhadap isu negatif mengenai MKJP, serta alasan lain seperti keinginan untuk memiliki anak lagi dalam waktu dekat. ${ }^{7}$

Hal ini sejalan dengan penelitian Kurniawan (2017) yang menjelaskan bahwa informan tidak mengetahui konsep dari Metode Kontrasepsi Jangka Panjang (MKJP), selain itu informan memilih sikap yang pesimis terhadap MKJP, sedangkan untuk aspek kepercayaan informan tidak memiliki kepercayaan larangan dalam penggunaan MKJP. Penyebab rendahnya penggunaan MKJP yaitu rendahnya kualitas pelayanan yang tidak sesuai dengan standar baku mutu pelayanan $\mathrm{KB}$, serta kurangnya dukungan dari keluarga (suami). ${ }^{8}$

Penggunaan kontrasepsi jangka panjang pada wanita usia subur menurut data di Indonesia masih tergolong rendah yaitu 4,7 persen. Metode kontrasepesi jangka panjang salah satunya adalah IUD. Sehingga perlu di lakukan penelitian untuk menggali faktor apa saja yang mempengaruhi wanita usia subur untuk akhirnya memilih menggunakan KB IUD dan alasan wanita usia subur untuk tidak memilih IUD. Universitas Indonesia sebagai kampus tertua dan yang mempelopori masyarakat untuk menjadi sehat, gambaran penggunaan kontrasepsi pada mahasiswa FKM menjadi penting, untuk melihat bagaimana perilaku penggunaan KB pada mahasiswa yang sudah memiliki pemahaman akan hal itu dan bagaimana kelak di masyarakat mereka dapat 
melakukan promosi yang baik agar masyarakat bisa memilih KB terbaik.

\section{Metode Penelitian}

Penelitian ini merupakan penelitian kualitatif dengan metode wawancara mendalam. Penelitian ini dilakukan pada 20-25 April 2018 di Fakultas Kesehatan Masyarakat Universitas Indonesia. Pemilihan informan untuk penelitian kualitatif dilakukan dengan menetapkan subjek yang akan dijadikan informan sesuai dengan kriteria yang telah ditentukan. Adapun kriteria informan dalam penelitian ini adalah: (1) Wanita usia subur yang sudah menikah dan merupakan mahasiswa Fakultas Kesehatan Masyarakat Universitas Indonesia dan (2) Menggunakan metode kontrasepsi IUD dan non IUD. Prinsip pengambilan sampel dalam penelitian kualitatif adalah kecukupan dan kesesuaian. Informan yang dipilih akan dibagi menjadi 2 kelompok yaitu informan yang menggunakan IUD dan tidak menggunakan IUD.

Pada saat wawancara mendalam, peneliti melakukan analisa terhadap pertanyaan atau jawaban jika didapati informasi yang kurang sesuai dengan tujuan penelitian maka peneliti akan melanjutkan pertanyaan lagi sampai memperoleh data yang sesuai. Peneliti melakukan survei pendahuluan kepada informan yang sudah menggunakan IUD dan non IUD terlebih dahulu untuk menguji validasi panduan wawancara mendalam yang akan digunakan pada informan. Kemudian untuk uji validasi data kualitatif akan menggunakan triangulasi data (triangulasi Sumber dan triangulasi analisis). Instrumen dalam penelitian ini adalah pedoman wawancara, alat dokumentasi (perekam suara dan kamera).

Dilakukan pengolahan data secara manual dari hasil wawancara mendalam sesuai dengan tujuan penelitian dan selanjutnya dianalisis dengan metode content analysis. Data yang dikumpulkan adalah data yang bukan angka sehingga analisis data dimulai dengan menulis hasil wawancara dan diinterpretasikan serta disajikan dalam bentuk narasi.

\section{HASIL}

Penelitian dilakukan terhadap 12 informan yang kemudian dibagi dalam 2 kelompok yaitu kelompok IUD dan non IUD.

\section{A. Gambaran Karakteristik Informan/ Subyek Penelitian}

Terdapat 6 informan yang menggunakan KB IUD, usia paling muda yaitu 33 tahun dan yang tertua yaitu 43 tahun. Jumlah anak informan KB IUD minimal 2 orang dan maksimal 4 orang. Dan terdapat 6 informan yang menggunakan KB non IUD, usia paling muda yaitu 29 tahun dan yang tertua yaitu 40 tahun. Jumlah anak informan KB non IUD minimal 2 orang dan maksimal 4 orang. Alat $\mathrm{KB}$ yang digunakan paling banyak yaitu $\mathrm{KB}$ Kalender dan yang paling sedikit yaitu kondom dan Metode Operasi Wanita (MOW).

\section{B. Faktor Predisposisi: Pengetahuan, Sikap dan Perilaku}

Pada informan pengguna KB IUD maupun non IUD, ketika ditanyakan tentang tujuan dari $\mathrm{KB}$, semua informan mengatakan bahwa mereka mengetahui tujuan dari $\mathrm{KB}$ itu sendiri yaitu untuk menunda kehamilan dan mengatur jarak kehamilan. Jika dibandingkan informan pengguna IUD dan non IUD terkait pengetahuan tentang jenis dari KB secara keseluruhan tidak ada perbedaan. Informan pengguna IUD mengetahui lebih banyak mengenai KB IUD dan berpendapat bahwa KB IUD lebih baik daripada $\mathrm{KB}$ yang mengandung hormonal, sedangkan pada informan non IUD setengah dari keseluruhan informan mengatakan bahwa setiap KB terdapat keuntungan dan kerugiannya.

Sikap informan terhadap pemilihan KB IUD dapat diketahui dari pemilihan jenis KB yang 
sesuai dengan persepsi informan dan motivasi yang mendukung. Pada informan pengguna IUD ketika ditanyakan setuju dengan $\mathrm{KB}$ jenis apa, maka seluruhnya menyatakan setuju dengan penggunaan IUD dan pada informan pengguna non IUD, sebagian besar tidak setuju menggunakan IUD. Berkaitan dengan motivasi informan menggunakan KB IUD, sebagian besar informan pengguna IUD menyatakan karena penggunaannya jangka panjang sehingga jarak kehamilan terkontrol dan tidak perlu berkali kali datang ke fasilitas pelayanan kesehatan. Motivasi pada informan pengguna KB non IUD menunjukkan bahwa sebagian besar informan memiliki motivasi menghindari efek samping

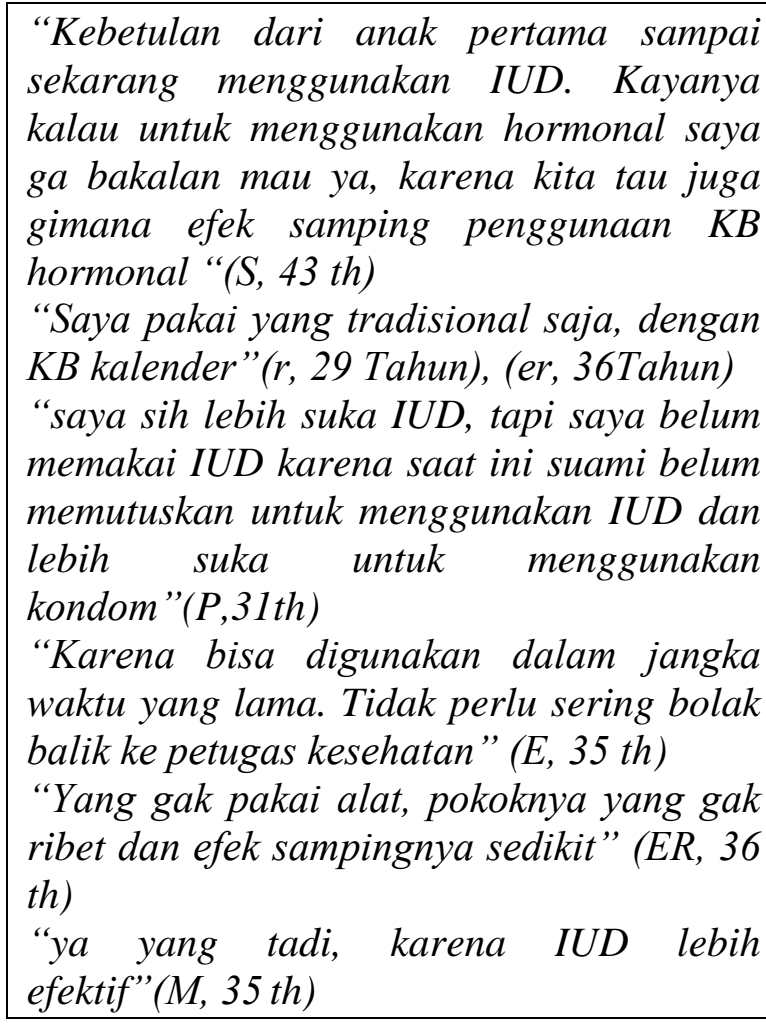

Alasan penggunaan KB IUD dan tidak memilih jenis KB yang lain pada sebagian besar informan adalah karena efisien, dalam hal ini harga yang tidak terlalu mahal dengan waktu pemakaian yang panjang dan tidak perlu bolak balik ke fasilitas pelayanan kesehatan. Pada Pengguna KB non IUD, seluruh pengguna $\mathrm{KB}$ menyatakan tidak memilih jenis $\mathrm{KB}$ yang lain karena mencari yang mudah, tidak ada efek samping dan tidak perlu datang ke tenaga kesehatan.

\section{Faktor Enabling}

Faktor mengenai ketersedian KB IUD. Pada informan pengguna IUD, ketika ditanyakan tentang pelayanan KB maka semua informan mengatakan bahwa mereka tidak merasa kesulitan untuk mendapatkan pelayanan KB, terkhusus KB IUD. Selain jarak yang tidak jauh, dalam penyampaian informasi mengenai IUD sudah sangat jelas. Tenaga kesehatan memberikan pelayanan yang sangat baik dan sangat terbuka. Pada informan pengguna non IUD, ketika ditanyakan tentang pelayanan KB maka semua informan mengatakan bahwa mereka menjawab pelayanannya bagus, berkualitas.

"Nggak sih, semua welcome di seluruh
fasilitas kesehatan ada, sudah tersedia
IUD dan tenaga teknisnya pun sudah
berpengalaman semua
pemasangan IUD" (M, 35 tahun)

Dilihat dari ketersediaan pelayanan KB seperti yang dijelaskan pengguna KB IUD dan non IUD bahwa pelayanan MKJP di tempat pelayanan $\mathrm{KB}$ mudah didapat.

\section{Faktor Reinforcing}

\section{Terdiri dari dukungan tenaga kesehatan, dan keluarga.}

Dukungan dari tenaga kesehatan terhadap pemilihan KB diantaranya adalah dari dokter spesialis kandungan, bidan, dan juga perawat. Semua informan yang menggunakan KB IUD mengatakan bahwa mereka mendapat dukungan dari tenaga kesehatan terkait dengan metode KB yang mereka pilih yaitu IUD. Untuk informan dengan pengguna Non IUD. Sebagian besar tenaga kesehatan mendukung pilihan yang telah ditentukan informan. Dan sebagian tenaga kesehatan lebih mendukung informan tersebut untuk menggunakan alat $\mathrm{KB}$ yang bisa mencegah kehamilan secara efektif sesuai dengan kondisi informan. Dukungan 
tenaga kesehatan yang berkaitan dengan informasi yang didapat ketika menggunakan $\mathrm{KB}$ pertama kali. Beberapa informan yang menggunakan KB IUD menyatakan saat pertama menggunakan KB tidak mendapatkan informasi dari tenaga kesehatan, mereka mencari sendiri informasi-informasi yang mereka butuhkan.

Berkaitan dengan dukungan keluarga, semua informan baik yang menggunakan IUD ataupun Non IUD menyatakan bahwa suami dan keluarga mereka mendukung atas pilihan $\mathrm{KB}$ yang mereka gunakan, berikut beberapa kutipan yang mereka katakan berkaitan dengan dukungan keluarga.

\begin{tabular}{|l|}
\hline "Suami saya menyetujui saya \\
menggunakan KB. Tapi Suami saya tidak \\
menyarankan saya pakai yang hormon \\
takutnya nanti saya gak pede. Jadi dia \\
ngasi pandangan ke saya kalau nanti \\
pakai hormon bisa menyebabkan \\
kegemukan dan lain sebagainya. Karena \\
suami saya juga tenaga kesehatan." (Ny. \\
IP, 39th/) \\
"Ibu dan suami saya sangat mendukung" \\
(Ny.L, 40 th), (Ny.W, 36th) \\
"suami ok ok aja"(Ny.ER, 36 th)
\end{tabular}

\section{Pembahasan}

\section{A. Gambaran Karakteristik Informan/ Subyek Penelitian}

Usia pada kelompok yang menggunakan IUD berada pada rentang 33-43 tahun, hal ini sejalan dengan penelitian Suharti tahun 2016 yang menyatakan bahwa semakin berumur seseorang maka akan semakin matang pola pikirnya dan pengetahuan tentang kontrasepsi yang lebih banyak, maka dapat meningkatkan pemakaian kontrasepsi IUD. ${ }^{9}$

\section{B. Faktor Predisposisi: Pengetahuan, Sikap dan Perilaku}

Pada informan pengguna KB IUD maupun non IUD semua informan mengatakan bahwa mereka mengetahui tujuan dari KB. Hal ini sejalan dengan penelitian sebelumnya yang menyatakan bahwa sebagian besar pengetahuan responden tentang tujuan $\mathrm{KB}$ adalah cukup. Tujuan KB merupakan aspek yang dinilai penting dalam pelayanan $\mathrm{KB}$ dan pemilihan KB. ${ }^{10}$ Hasil data SDKI 2017 juga menyebutkan bahwa pengetahuan diantara wanita berstatus kawin pada usia subur tentang KB tidak banyak bervariasi. ${ }^{6}$

Sikap informan terhadap pemilihan KB IUD dapat diketahui dari pemilihan jenis KB yang sesuai dengan persepsi informan dan motivasi yang mendukung. Ada hubungan antara tingkat pendidikan tinggi dengan kesadaran kontrasepsi. Hal ini sejalan dengan penelitian sebelumnya di Kenya. ${ }^{11}$

\section{Faktor Enabling}

Dilihat dari ketersediaan pelayanan $\mathrm{KB}$ seperti yang dijelaskan pengguna KB IUD dan non IUD, penelitian yang dilakukan oleh Rahayu (2017) juga menerangkan bahwa pelayanan MKJP di tempat pelayanan KB yang dipilih oleh wanita PUS sebagian besar telah tersedia. Ini menjelaskan bahwa saat ini ketersediaan pelayanan $\mathrm{KB}$ mudah didapat. ${ }^{7}$

\section{Faktor Reinforcing}

\section{Terdiri dari dukungan tenaga kesehatan dan keluarga.}

Dukungan dari tenaga kesehatan terhadap pemilihan $\mathrm{KB}$ dan informasi dari tenaga kesehatan menjadi hal yang penting saat ibu ingin menggunakan KB. Sebagian informan menyatakan bahwa mereka masih mendapatkan informasi yang kurang mengenai kontrasepsi, hal ini sejalan dengan data SDKI 2017 yang melaporkan bahwa masih kurangnya informasi yang diberikan oleh petugas kesehatan terhadap pengguna $\mathrm{KB}^{6}{ }^{6}$

Berkaitan dengan dukungan keluarga, semua informan baik yang menggunakan IUD ataupun Non IUD menyatakan bahwa suami dan keluarga mereka mendukung atas pilihan KB yang mereka gunakan. Hal ini sejalan 
dengan beberapa penelitian sebelumnya yang menyatakan bahwa ada hubungan dukungan suami pada ibu dalam pemilihan penggunaan metode kontrasepsi. ${ }^{12}$

\section{KESIMPUlan DAN SARAN}

Berdasarkan penelitian yang dilakukan, didapatkan informasi bahwa tidak terdapat perbedaan tingkat pengetahuan antara pengguna kontrasepsi IUD dan non IUD. Sikap informan terhadap perilaku penggunaan IUD. Dukungan Suami merupakan reinforcing factor, dari hasil penelitian terlihat bahwa baik informan pengguna IUD dan non IUD seluruhnya menyatakan dukungan suami yang mendorong memutuskan kontrasepsi yang mereka pilih. Faktor yang menghambat perilaku penggunaan kontrasepsi IUD adalah sikap dan faktor yang mendorong perilaku penggunaan IUD adalah dukungan suami sehingga intervensi yang mungkin dapat dilakukan adalah meningkatkan motivasi dan memperbaiki persepsi pengguna non IUD untuk kemudian memutuskan mengubah sikapnya dari tidak setuju menjadi setuju untuk menggunakan IUD, selain itu peran dukungan suami perlu ditingkatkan dengan berbagai intervensi.

\section{Daftar Pustaka}

[1] WHO. Maternal Mortality. 2016.

[2] Badan Pusat Statistik, Badan Koordinasi Keluarga Berencanan Nasional, Departemen Kesehatan, Macro International. Survei Demografi dan Kesehatan Indonesia 2012. Sdki. 2013;16.

[3] WHO, UNICEF, UNFPA, World Bank Group and the United Nations Population Division. Trends in 2000 to 2017 Trends in maternal mortality: 2000 to 2017. 2017. 104 p.

[4] Johnston RB. Arsenic and the 2030 Agenda for sustainable development. Arsen Res Glob Sustain - Proc 6th Int Congr Arsen Environ AS 2016. 2016;12-4.

[5] BKKBN. Batasan dan Pengertian MDK (Pemutahiran Data Keluarga) Survei Demografi dan Kesehatan Indonesia Jakarta Kementerian Kesehatan RI.

[6] Kemenkes RI, Badan Kependudukan dan
Keluarga Berencana Nasional, RISKESDAS. 2017 Survei Demografi dan. Riset Kesehatan Dasar 2018. 2018. 1-446 p.

[7] Rahayu S. Faktor-faktor Penyebab Rendahnya Penggunaan Metode Kontrasepsi Jangka Panjang. J IPenelitian Geogr. 2017;V(4):1-12.

[8] Kurniawan H NR. Perilaku Akseptor Dalam Memilih Metode Kontrasepsi Jangka Panjang (Mkjp) Di Poskesdes Anuta Singgani Kecamatan Mantikulore Kota Palu. J Prev [Internet]. 2017;8(April):1-58. Available from: rahmathidayatkesmas12@gmail.com

[9] Suharti S. Efektivitas Kie (Komunikasi, Informasi Dan Edukasi) Terhadap Penggunaan Kb Iud (Intra Uterine Devices) Di Wilayah Kerja Puskesmas Tanjung Rejo Kecamatan Percut Sei Tuan Kabupaten Deli Serdang. J Ilm Kebidanan IMELDA [Internet]. 2016;2(2):86-93. Available from: http://ojs.stikesimelda.ac.id/index.php/jiki/article/view/159/126

[10] Puja, Girsang ES, Sari DK. Gambaran Pengetahuan Wanita Pasangan Usia Subur Tentang Metode Keluarga Berencana modern di Kelurahan Tanjung Rejo Kecamatan Medan Sunggal tahun 2017. J Kedokt Methodist. 2017;11(1):26-30.

[11] Jalang'O R, Thuita F, Barasa SO, Njoroge P. Determinants of contraceptive use among postpartum women in a county hospital in rural Kenya. BMC Public Health. 2017;17(1):1-8.

[12] Sulastri S, ChichikNirmasari. Hubungan dukungan suami dengan minat ibu dalam pemakaian kontrasepsi iud di bergas. Akad Kebidanan Ngudi Waluyo Ung. 2013;2-7. 